\title{
Do Differences in Livestock Management Practices Influence Environmental Impacts?
}

\author{
Gary S. Kleppel* \\ Biology Department, State University of New York, Albany, NY, United States
}

Herbivore-carnivore interactions are fundamental to grassland ecosystem functionality and to the human cultures that have long depended on these ecosystems for their nutrition. However, a large literature has developed during the past century indicating that animal agriculture is responsible for numerous negative environmental impacts. In this paper, I review literature on some of the environmental impacts of two different livestock management approaches, industrial-conventional (IC) management and regenerative-multi-paddock (RM) management. I consider the null hypothesis that the environmental impacts of ruminant livestock production are independent of the approach used to manage animals and grazing lands. It evident in the literature that managed grazing ecosystems are complex, and for certain system attributes, such as forage quality and plant community structure, the better management system is difficult to discern. In other areas definitive differences in impacts appear clearly management

Edited by:

Rebecca Chaplin-Kramer, Stanford University, United States

Reviewed by:

Laura M. Cardenas, Rothamsted Research,

United Kingdom Rick Teague,

Texas A\&M AgriLife Research \& Extension Center at Stephenville, United States

*Correspondence:

Gary S. Kleppel gkleppel@albany.edu

Specialty section:

This article was submitted to Agroecology and Ecosystem Services,

a section of the journal Frontiers in Sustainable Food Systems

Received: 26 March 2020

Accepted: 05 August 2020 Published: 16 September 2020

Citation:

Kleppel GS (2020) Do Differences in Livestock Management Practices Influence Environmental Impacts? Front. Sustain. Food Syst. 4:141 doi: 10.3389/fsufs.2020.00141 diversity, and higher fungal: bacterial ratios than IC soils. Several impacts associated with livestock production appear to have less to do with grazing, per se, and more to do with support factors, such as feed production and manure management. The compilation of data from numerous sources suggests that RM management may reduce blue withdrawals and GHG emissions by $>50 \%$, relative to IC management. Accumulating data also suggest that a significant portion of anthropogenic $\mathrm{CO}_{2}$-eq emissions can be removed from the atmosphere and stored in the soil by applying RM management practices. Finally, it is suggested that while research design may affect the outcomes of some studies, the quality and quantity of the science may not resolve many discrepancies in the data. It is suggested that the viability and sustainability of animal agriculture may depend upon broadening the goals of practitioners to include both food production and the restoration and protection of agricultural ecosystem services.

Keywords: meat production, regenerative agriculture, multi-paddock livestock management, industrial agriculture, conventional livestock management, livestock impacts

\section{INTRODUCTION}

Research conducted over nearly a century identifies clear connections between animal agriculture and environmental disruption. Livestock grazing has long been associated with biodiversity loss in plant and wildlife communities, the dispersal of invasive species, degradation of soil structure, and desertification (Daubenmire, 1940; Savory, 1983; Allen et al., 1991; Savory and Butterworth, 1999; Drewry, 2006; Harrison and Bardgett, 2010; Wirsenius et al., 2010; Alkemade et al., 2013). Cattle 
grazing and livestock feed production are responsible for $>65 \%$ of the deforestation that has taken place in Brazil and other tropical and subtropical regions (Vale et al., 2019). Animal agriculture is an important source of ammonia, greenhouse gas emissions (GHG) [Parris, 2011; USEPA (U.S. Environmental Protection Agency), 2017; Food Agriculture Organization, 2019] and blue water withdrawals [USGS (U.S. Geological Service), 2005; Rotz et al., 2019]. Runoff from livestock and feed production operations are significant non-point aquatic contamination sources [Agouridis et al., 2005; USEPA (U.S. Environmental Protection Agency), 2017].

These obviously negative impacts contrast markedly with the natural historical record documenting the roles of herd forming ungulates in maintaining the functionality of grassand rangeland ecosystems and the human cultures that have depended on these systems for hundreds of millennia (Oksanen et al., 1981; Frank et al., 1998; Baltica and Boskovica, 2015). Large ungulates are keystone species in wild grassland ecosystems globally, supporting higher trophic transfer efficiencies than herbivores in most other kinds of terrestrial ecosystems (StuartHill and Mentis, 1982; Frank et al., 1998). An estimated 168 million ruminants, including 50-60 million bison roamed the grasslands of pre-Colombian North America, supporting enormous soil fertility, and biodiversity in the plant communities they grazed (Frank et al., 1998; Skarpe and Hester, 2010). Greenhouse gas production, particularly methane production, by these ungulates was equivalent to that produced by modern livestock [Smith et al., 2016; USEPA (U.S. Environmental Protection Agency), 2020]. Massive ungulate herds also grazed and in some cases continue to graze the grasslands of Eurasia and Africa (Janis, 2010) and although the carbon and nitrogenous gas produced by these mammals once raised GHG levels in the atmosphere, they are not known to have significantly altered global climate (Smith et al., 2016). These wild, herd-forming ungulates did, however, represent critical nutritional and cultural resources to pre-agricultural human societies.

One must ask why large ruminants that have so profoundly contributed to the fertility and well-being of terrestrial ecosystems and the humans who inhabited them, have today become anathema to human and environmental health. Certainly, domestication has not changed the anatomies or physiologies of herbivores in meaningful ways. It is unlikely, then, that the negative impacts of animal agriculture are due to the species being produced. It seems more likely that livestock management practices determine impacts. It should, therefore, be possible to mitigate at least some impacts of animal agriculture by modifying production practices.

In this paper I address the null hypothesis that the environmental impacts of animal agriculture, particularly those associated with the production of ruminant species, are independent of management. I used data from the technical literature and popular media in this investigation. The focus of the paper is on livestock management practices in industrialized countries, including but not limited to the United States, the United Kingdom, Canada, Australia and the European Union, as well as certain developing countries, such as Brazil. Comparisons were made between two very different management models. One of these is generally associated with the industrial model of agriculture and based on pasture management practices that will be referred to as "conventional grazing." The other is consistent with the regenerative model of agriculture and a set of livestock management practices collectively referred to as "multi-paddock grazing" (MP). Throughout this paper I will use the abbreviation IC to refer to the industrial-conventional management collective and RM to refer to the regenerative-multi-paddock management collective. In many cases I will refer to a system by its collective management approach, i.e., IC or RM. However, there are times, particularly in the experimental literature, when the collective management approach is not specified but the grazing practice (e.g., conventional or MP) is. Furthermore, there are times when data from several grazing operations or experimental systems are considered together without specification of an overall or collective strategy. In these cases, I will confine my description to the grazing practice (conventional or MP) rather than collective approach (IC or RM). It is recognized that animal agriculture exists along a continuum of practices with many operations combining elements of both industrial and regenerative practice.

To be clear, a variety of "traditional" practices (as distinguished from conventional practices) are used to manage livestock on pastures and rangelands in both the developed and developing world. These vary along a continuum from relatively unmanaged seasonal grazing (e.g., traditional Scottish and Icelandic sheep farming) to carefully managed seasonal livestock migrations (e.g., African Maasai cattle herders; French mountain shepherds, see Meuret and Provenza, 2014). In this paper, I will not dwell on the many, often ancient, practices used by traditional herding cultures, particularly in the developing world. Many of these are under stress from anthropogenic (e.g., Mongolian herders) and environmental forces (e.g., Saami reindeer herders of Scandinavia; Changpa nomads of the Kashmiri high-ice deserts). They should become the focus of further research, as they contribute to both fertility and stress in agricultural landscapes. The focus of this paper, however, is on comparing conventional grazing within the context of the industrial agricultural model, and multi-paddock grazing as incorporated into the regenerative agricultural model.

\section{INDUSTRIAL AGRICULTURE AND CONVENTIONAL LIVESTOCK PRODUCTION}

Modern industrial agriculture originated in Europe and the United States during the mid-eighteenth century in parallel with the Industrial Revolution. All efforts in agriculture were focused on boosting production and efficiency to meet the growing demand for food created by the massive demographic shift from the countryside to emerging urban manufacturing centers (Pollard, 1981; Wiesner et al., 2015). After the first and second World Wars mechanization and the development of synthetic fertilizers approximately doubled crop production. Synthetic pesticides (e.g., DDT) permitted the creation of large-scale crop monocultures year after year (Kleppel, 2014; Bellis, 2018). During the second half of the twentieth century the Green Revolution 
brought selectively bred plant varieties, especially cereal grains, to the developing world (Borlaug, 1970, 2002), but possibly at an unsustainable cost in terms of fossil fuels use, synthetic fertilizer applications, and blue water withdrawals (Brown, 1970; Cribb, 2010; Shiva, 2016). Today, as genomics, artificial intelligence and other information technologies surge, a new revolution in industrial agriculture is underway. Its success will be measured by the role it plays in feeding an exploding human population in the face of climate change and resource decline.

Optimization of production is the focus of modern industrial animal agriculture. This is often accomplished by finishing livestock in confined animal feeding operations (CAFOs). While increasingly limited in Europe (Imhoff, 2010), CAFOs are widely used in the US. Typically, beef cattle are moved from grazing lands to the CAFO at $\sim 6$-months of age and are ready for slaughter 3-5 months later. Dairy cattle and swine may be confined during much or all of their lives. The CAFO maintains livestock at high densities. Energy rich rations consisting of silage and/or pelletized grains, are typical feeds. Growth stimulants, including hormones, as well as certain antibiotics delivered at sub-medicinal levels that stimulate citric acid cycle activity, are widely used in the US (less so, outside of the US) to increase the rate of weight gain (Pollan, 2006; Kleppel, 2014). The US Food and Drug Administration [FDA (U.S. Food and Drug Administration), 2013; FDA (U.S. Food Drug Administration), 2019] has tightened control over (but not banned) the use of antibiotics in animal feeds due to their role in the production of antibiotic resistant, pathogenic bacteria [Feingold et al., 2012; FDA (U.S. Food and Drug Administration), 2013; FDA (U.S. Food Drug Administration), 2019]. Although beyond the scope of this paper, CAFO practices, which reduce finishing times by $30-50 \%$ relative to finishing on pasture, have been criticized as inhumane and unsafe (Schlosser, 2001; Pollan, 2006; Ebner, 2017). Nonetheless, the industrial model of livestock production is the globally dominant meat production system, accounting for more than $80 \%$ of the meat produced in the United States (Schlosser, 2001; Ikerd, 2008).

Conventional livestock management which, in this paper, refers to the on-farm portion of livestock production, prior to movement to the CAFO, dovetails with the industrial model in its focus on specialization and monoculture, in its extensive use of chemical and other inputs and its reliance on grainbased or grain supplemented nutrition for ruminants, even when animals are on pasture. Stock densities on pasture tend to be relatively low and stock rotation (i.e., movement to fresh pasture) tends to be relatively infrequent (weeks to seasons) if it occurs at all. Overgrazing is common in conventional grazing systems and may be compensated for by supplementing with hay, silage and/or pelletized grain.

\section{REGENERATIVE AGRICULTURE AND MULTI-PADDOCK GRAZING}

Regenerative agriculture focuses at least as strongly on the restoration and management of soil health and agro-ecosystem functionality as on production (Doran et al., 2002). Doran (2002) defines soil health as "... the capacity of a living soil to function within natural or managed ecosystem boundaries, to sustain plant and animal productivity, maintain or enhance water and air quality, and promote plant and animal health."

Regenerative agriculture has its roots in the early to midtwentieth century, beginning with the work of Howard (1940, 1947), Balfour (1943) and the emergent organic and (what became) the holistic management and sustainable agriculture movements of the 1960s and beyond. The regenerative approach is a response to evidence that soil health, functionality and quality have been lost or have deteriorated to the extent that much of the earth's arable soils are incapable of producing nutrient dense food and have lost the capacity to support essential ecosystem services (Pimentel et al., 1987; Crosson et al., 1995; Lal, 2001, 2019; Pimentel and Burgess, 2013; Montgomery, 2017). As such, regenerative operations frequently employ organic or "nature-based" practices (Brown, 2018) with the co-equal goals of producing nutrient dense food while restoring and managing environmental quality (Bouma, 2002; Jackson, 2002).

Pasture-based livestock production is key to regenerative farming and ranching. Pasture-based producers feed ruminant livestock primarily on forages, hay, and/or haylage. Omnivorous, non-ruminant livestock, such as swine and poultry, usually receive some grain-based feed supplements. Stock densities of ruminants in this system are usually 2-4 times higher than in conventional grazing systems and rotation to fresh pasture generally occurs every $0.5-3$ days (Flack, 2016). A rotational cycle through a subdivided pasture system, or multi-paddock system, should require at least 30 days, but rotational cycles of 60 to >100 days are not uncommon (Gerrish, 2004). Rotational cycles can be adjusted to accomplish ancillary goals, such as invasive plant management, or to respond to changing vegetation, weather patterns (e.g., drought) or other variables (see Kleppel et al., 2011; Girard Cartier and Kleppel, 2015; Bishopp, 2020). Several workers have described these methods in detail, using such terms as holistic planned grazing, managementintensive grazing and intensive rotational grazing (Savory, 1983; Savory and Butterworth, 1999, 2016; Gerrish, 2004; Flack, 2016; Salatin, 2019). Collectively, they are referred to as multi-paddock (MP), or adaptive multi-paddock (AMP) livestock management (Teague et al., 2011; Rowntree et al., 2019). Multi-paddock management attempts to mimic the evolved herding behaviors of wild, ungulates (Voisin, 1959; Acocks, 1966a,b). Protagonists of multi-paddock management claim that this approach enhances soil fertility and health, reduces overgrazing, and reduces disease and morbidity within the herd. In this paper, I will examine some of these claims.

\section{Wild Ungulates and the Multi-Paddock Approach to Grazing}

About $40 \%$ the Earth's land area is suitable for agriculture and about one-third of that can support large scale crop production (Revelle, 1976). The remainder will only support animal agriculture. Whether produced conventionally or by RM practices, most domesticated ruminants forage on pasture or rangeland during at least a portion of their lives. The way land is 
used, and the amount of land used for grazing differ with practice, as do the responses of the soil, vegetation and water supplies to the stocking rates and activities of the animals.

Observations of wild, herd forming ungulates inform RM practice. Studies in the African Serengeti and Yellowstone National Park, Wyoming, USA have demonstrated that grazers, particularly large herd-forming ungulates, migrate across landscapes in response to stimuli associated with the seasonal growing cycle of the plant community (McNaughton, 1985; Frank et al., 1998). "Green waves" of primary production during the rainy season in the Serengeti and the vernal thaw in Yellowstone, trigger these migrations. Herd trajectories are refined by gradients in macro-nutrient and mineral concentrations in the forage (McNaughton, 1990). Plant communities in the Serengeti are, not surprisingly, dominated by grazing-tolerant species (McNaughton, 1984; Archibald, 2008), which tend to grow close to the ground and to be shorter in height than the same species in un-grazed grasslands. Nonetheless, compensatory biomass production in grazed plant communities tends to be higher than in grasslands from which large grazers have been excluded (McNaughton, 1984, 1986). Furthermore, studies in both wild and agricultural landscapes suggest that plant community species richness tends to be higher in ecosystems grazed by herd-forming ungulates (unencumbered by human artifacts) than in un-grazed systems, exclosures, or un-grazed sections within a particular landscape (Frank, 2005; Marion et al., 2010; Girard Cartier, 2017).

The capacity of soil-plant-herbivore interactions to translate from wild to agricultural ecosystems predicts the nature and extent of impacts that livestock may have on soil, forage, and aquatic resources. These, I suggest, will be determined by the way the livestock is managed within the grazing ecosystem.

\section{ENVIRONMENTAL IMPACTS OF ANIMAL AGRICULTURE}

This paper compares IC and RM practice in four categories of environmental impacts associated with livestock agriculture. These are: (i) impacts to plant communities and soil health; (ii) impacts to water and soil-water interactions; (iii) impacts from agricultural ammonia $\left(\mathrm{NH}_{3}\right)$ emissions; and (iv) impacts associated with climate change.

\section{Impacts to Plant Communities and Soil Health}

That livestock activities, including grazing, egestion and excretion, and trampling affect the structure and functioning of grassland ecosystems has led some workers to suggest that grazing and animal agriculture are ecologically destructive (Belsky, 1987; Mligo, 2015). Logic, however, causes one to question that notion, and numerous studies, both empirical and model-based, have demonstrated that a multiplicity of geophysical, biological, behavioral, and natural historical factors, functioning over seasonal to evolutionary timescales influence the ways that wild and domesticated grazers affect grassland ecosystems (McNaughton, 1985; Milchunas et al., 1988;
Milchunas and Lauenroth, 1993; Cingolani et al., 2005; Patra et al., 2005; Villalba and Provenza, 2009; Hilario et al., 2017). Plant community biomass and composition, as well as plant physiology are influenced by the timing and intensity of grazing (Hayes and Holl, 2003; Frank, 2005). For example, Daubenmire (1940), studying the effects of domesticated livestock grazing on plant communities in the bunchgrass prairie of Washington state, USA, reported that heavy grazing resulted in severe defoliation and changes in dominance patterns and other structural variables in the prairie grass community. Furthermore, he noted that heavy grazing sometimes created areas of bare ground and altered patch structure. The effects of cattle grazing on the bunchgrass prairie community varied with the temporal onset of grazing and its persistence.

Interestingly, the factors that determine grazing intensity are often vaguely described in the literature and vary from one study to the next. Research published more than a half century ago, however, provides guidance on what determines grazing intensity. Voisin (1959) noticed that wild ungulates move continuously across a landscape. More recently, OwenSmith et al. (2010) suggested that herd movements tend to be continuous over a hierarchy of spatial scales. Conventionally managed livestock, however, may remain in a single pasture for an entire grazing season over multiple years. Acocks (1966a; 1966b, cf. Hoffman, 2003) observed that wild, herd forming ungulates aggregate at relatively high densities. For example, Venter et al. (2017) reported wildebeest herds of $>20$ tons $\mathrm{ha}^{-1}\left(>100\right.$ head $\left.\mathrm{ha}^{-1}\right)$ in a $24 \mathrm{~km}^{2}$ region of the Serengeti. Conversely, domesticated livestock are often stocked at much lower densities [e.g., 1.2-2.5 tons ha ${ }^{-1}$; UMass (Sustainable UMass), 2020] on pasture and rangeland, and moved infrequently, if at all. At low stocking rates livestock graze selectively, ultimately overgrazing patches and creating bare ground that becomes susceptible to drying, capping and erosion (Savory and Butterworth, 1999). Soil structural integrity deteriorates rapidly under these conditions, and the capacity of the soil to retain water and carbon is lost (Savory and Butterworth, 1999, 2016; Gerrish, 2004; Lal, 2004, 2015). Even in pastures composed of monocultures or only a few plant species, continuous or near-continuous grazing will produce these same outcomes (Massy, 2018).

Following on the observations of Acocks and Voisin, workers hypothesized that by mimicking the aggregation and movement patterns of wild ungulates, livestock could be managed without damaging grassland ecosystems (Goodloe, 1969; Savory, 1978, 1983; Savory and Parsons, 1980; Savory and Butterworth, 1999, 2016; Teague et al., 2009). Among the principal findings of researchers and practitioners of MP management are that frequent rotation and relatively long periods of pasture rest are key to pastoral ecosystem functionality and livestock health (Gerrish, 2004; Flack, 2016; Savory and Butterworth, 2016). In a typical multi-paddock operation, the vegetation in a single paddock experiences intense grazing pressure for a short period of time. This is followed by a period of pasture rest that varies with vegetation growth rates, such that over the course of the season the grassland is only lightly impacted. Some pastoralists have suggested that the rest period afforded to a grassland, more 
than the stocking rate (which can vary widely, e.g., from 5 to 125 tons $\mathrm{ha}^{-1}$ ), may be critical to determining the impacts of grazers in a landscape (Salatin, 2019). Badgery (2017) compared the effects of high rotation frequencies and long periods of pasture rest (57 d, $114 \mathrm{~d}$, or flexible rest period) on forage biomass and beef cattle production with conventional (continuous) grazing. While the effects varied with plant species composition, overall plant biomass and ground cover were significantly higher in the multi-paddock than the conventionally grazed system. Production was statistically similar in both experimental grazing systems. Teague et al. (2013) have been critical of such studies, pointing to the difficulties of designing experiments in which one attempts to hold a suite of secondary variables constant while the single variable of interest (e.g., rest period) is manipulated.

Several studies suggest that livestock managed according to the multi-paddock model can increase plant species richness and the functionality of grassland ecosystems (Booysen and De, 1969; Howell, 2008; Brown, 2018). Teague et al. (2011) observed higher production of seral grasses, and lower incidences of bare ground in pastures in north central Texas that used AMP practices relative to conventionally grazed pastures. Similarly, Girard Cartier and Kleppel (2017), Teague and Barnes (2017), and Kleppel (2019) observed higher plant biodiversity, forage biomass or both in pastures in upstate New York and north central Texas managed by MP and RM practices relative to pastures managed conventionally. Cassidy and Kleppel (2017) reported that Savannah sparrow (Passerunculus sandwichensis) and Bobolink (Dolichonyx oryzivorus) abundances were 2-3 times higher in pastures managed by MP and RM practices than in conventionally managed pastures.

Not all comparisons of MP and conventional grazing support these observations. In fact, there is a lack of consensus on the benefits of MP and RM management to plant community structure or function relative to IC and conventional grazing practice (Gosnell et al., 2020 and references therein). Teague et al. (2013) suggested possible explanations for contradictory results, but disagreements remain about the efficacy of multipaddock techniques relative to conventionally managed grazing (e.g., Barnes and Denny, 1991; McCollum et al., 1999; Briske et al., 2008; Hawkins et al., 2017; and others). These discrepancies may be due, in part, to differences in the ways managers respond to environmental variability (Voisin, 1959).

The effects of grazers on soil structure and composition vary with the timing of deployment, rotation frequency, and species, breeds, and stocking rates. For example, grazing during dry or wet periods can have significant effects on soil structure, which will vary depending upon soil type, slope and landscape roughness, and the nature of vegetative cover. Verchot et al. (2002) observed that nitrogen (N) mineralization and immobilization proceeded at rates nearly an order of magnitude higher in the wet bottomlands of Yellowstone National Park (YNP) than in dry uplands areas, independent of whether the landscape was grazed or not grazed by wild ungulates. Conversely, Frank et al. (2000) reported significant differences in soil $\mathrm{N}$-dynamics in grazed and ungrazed portions of the northern winter range of YNP. In livestock grazing systems, relationships among variables may be management-dependent. Girard Cartier (2017), working with sheep, reported differences in soil N-dynamics in bottomland and upland sites in upstate New York, USA that were associated with both landscape attributes and management practices (MP vs. continuous grazing).

The intimate coupling that exists between the soil microbial community, the plant community, and the activities of ruminants is critical to the functioning of both wild grassland and pastoral ecosystems (Bardgett et al., 1997, 2001; Oates et al., 2018). Grazing has a strong influence on this functionality and on the way livestock management can influence the structure and stability of both forage and soil microbial communities. For example, heavy grazing often results in severe defoliation and the production of highly labile root exudates that favor the growth of bacteria in the rhizosphere. Conversely, light grazing results in production of less labile root exudates that support the growth of fungal species (Bardgett and Leemans, 1995; Bardgett et al., 1998). One would expect, therefore, that fungal:bacterial $(\mathrm{F}: \mathrm{B})$ ratios would be higher in MP soils than conventionally managed soils, if indeed, MP management represents a form of "light" grazing. This is important because, as a rule, higher F:B ratios reflect greater soil organic matter (SOM) stability and greater water holding capacity. Furthermore, diversity is key to the stability of soil microbial communities and therefore to the interdependent functioning of the soil-forage-grazer system. Few studies, however, have compared soil microbial community structures and compositions in differently managed grasslands. Teague et al. (2011) in north central Texas, and Kleppel (2019) in upstate New York independently observed higher F:B ratios and greater microbial diversity in the soils of pastures managed by MP practices than by conventional practices. Multivariate analyses (Kleppel, 2019) revealed that different variables may drive changes in microbial biomass in soils of differently managed pastures, even when the pastures are near each other. These findings support the hypothesis that grazing management practices can influence the structure and functioning of the soil microbiome and thereby the structure of the soil itself.

\section{Impacts to Water and Soil-Water Interactions Water Pollution and Soil Degradation}

It is not news that agriculture contributes significantly to water pollution. Runoff linked to the management of livestock and manure, as well as feed production are key contributors to that signal (Parris, 2011). The impacts of animal agriculture vary with regional differences in soil type, topography, weather, climate, and vegetation. The effects of RM and IC practices on water quality differ over a variety of scales. On Texas ranches, switching from multi-paddock to heavy continuous grazing practices resulted in increased runoff and losses of sediment, inorganic nitrogen, and phosphorus on the order of 140-160\% (Park et al., 2017). Switching from continuous to MP grazing practices resulted in comparable decreases in erosion and nutrient leaching.

While ultimately, soil type and water delivery rate are the overarching determinants of infiltration rate, livestock, and 
pasture management practices can alter this process (Laycock and Conrad, 1967; Savory and Butterworth, 1999; Franzluebbers et al., 2012). However, comparisons between the effects of livestock management practices on water infiltration and soil compaction (i.e., bulk density) are inconsistent. Abdel-Magid et al. (1987) observed no effect of rotational frequency or stock density on bulk density, but infiltration declined at higher stock densities in sandy loam soils of the high-plains grasslands near Cheyenne, Wyoming, USA. Thurow et al. (1986) reported that in semi-arid Texas grasslands, infiltration rates, and bulk densities were less severely impacted by multi-paddock grazing than by continuous grazing, though Warren et al. (1986a) noted that both stock density and vegetation type may affect soil compaction and infiltration. Warren et al. (1986b) also reported that water infiltration into soils devoid of vegetation decreased significantly under intensive rotations with impacts increasing as a function of simulated rainfall. Teague et al. (2020) expressed concern about the artificiality of the design of these experiments. Kleppel (2019) studying grasslands grazed by large and small ruminants, as well as un-grazed hayfields, observed no effect of management practice (MP v. conventional v. hayfields) on soil moisture or infiltration rates, but found significantly less compaction (lower bulk densities) of MP soils than of conventionally grazed or hayfield soils in the silty-clay loams (principally Angola, Burdette, and Tuller-Green) and hilly landscapes of upstate New York.

\section{Blue Water Withdrawals}

Agriculture is water intensive. Between 30 and $40 \%$ of blue water withdrawals in the United States and $\sim 60-70 \%$ of blue water withdrawals worldwide are associated with agricultural activities (USGS (U.S. Geological Service), 2005; Schlosser et al., 2014). In the US, only about $7.5 \%$ of agricultural water use is directed toward livestock production and only $3 \%$ is consumed as drinking water by cattle (Rotz et al., 2019). Approximately $90 \%$ of all blue water withdrawals for agriculture are used for irrigation (91.7 TL) [USDA/ERS (U.S. Department of Agriculture/ Economic Research Service), 2019a]. About 60\% of that is for production of livestock feed crops: corn (25\%), forage (18\%) and soybeans (14\%) [USDA/ERS (U.S. Department of Agriculture/ Economic Research Service), 2019b].

Rotz et al. (2019) conducted an extensive and elegant analysis of the environmental footprint of beef production in the United States. The authors used an Integrated Farm System Model (IFSM; Rotz et al., 2016) to estimate energy use, greenhouse gas (GHG) emissions, reactive $\mathrm{N}$ releases and blue water withdrawals for production of both traditional beef breeds and culled dairy cattle. They reported a farm-to-gate blue water consumption of 23.2 TL for the US herd, or 2,095 L/kg of carcass weight (CW). Only $0.7 \mathrm{TL}$ nationally, or $62.9 \mathrm{~L} / \mathrm{kg} \mathrm{CW}$ of total blue water withdrawal accrues from drinking and $6-11 \%$ of the water consumed by a steer is returned to the hydrological cycle by excretion (as urine and dung) and respiration (Nader et al., 1998). The fate of excreted water depends on practice. In pasturebased practice, water in urine and dung is returned to the soil where it may serve as a vehicle facilitating microbial contact for nutrient regeneration. In a CAFO, urine and dung are treated as
TABLE 1 | Farm-to-gate blue water requirements for traditional beef cattle breeds produced by industrial-conventional (IC) and regenerative-multi-paddock (RM) management.

\begin{tabular}{|c|c|c|c|}
\hline \multicolumn{2}{|c|}{ Industrial-conventional $^{a}$} & \multicolumn{2}{|c|}{ Regenerative-multi-paddock ${ }^{\text {b }}$} \\
\hline & Liters $\mathbf{k g}^{-1} \mathbf{C W}$ & & Liters $\mathbf{k g}^{-1} \mathbf{C W}$ \\
\hline Drinking & 62.9 & Drinking & 62.9 \\
\hline Feed production & 2032.1 & Feed production - min & 201.2 \\
\hline \multirow[t]{3}{*}{ Total requirement } & 2095.1 & Feed production - max & 955.1 \\
\hline & & Total requirement - min & 264.1 \\
\hline & & Total requirement - max & 1018.0 \\
\hline
\end{tabular}

a Data from Rotz et al. (2019).

${ }^{b}$ To estimate minimum (min) and maximum (max) feed production requirements, i.e., use factors relating to production of grain feeds, as well as synthetic chemical inputs were removed from the use factor list (Rotz et al., 2019, their table, p. 3) to create a list of RM use factors. Then, the minimum water requirement for $R M$ feed production $=(\Sigma$ minimum values for $R M$ use factors $\Sigma$ minimum values for all use factors) $\times$ Feed production water requirement (2032.1 $\mathrm{L} \mathrm{kg}^{-1} \mathrm{CW}$ ). The maximum water requirement for $\mathrm{RM}$ feed production was estimated by replacing minimum use factors by maximum use factors.

contaminants and may be composted in sumps or other waste management systems.

Rotz et al. (2019) did not distinguish between IC and RM blue water withdrawals. However, using their Table 1 (p. 3), which provides blue water use factors for feed production, it was possible to separate factors associated with IC and RM operations (Table 1 in this paper). I used Rotz et al.'s blue water withdrawal estimates for IC practice, but because minimum and maximum values were provided for some feed production use factors, I preserved the range of estimates of water withdrawals associated with feed production in RM operations. The relative difference between blue water use for feed production by the two practices is substantial. IC practices require $53.1-90.1 \%$ more water than $\mathrm{RM}$ practices due to the lower dependence of RM practice on grain-based feeds. For a pasture-based RM operation between 251.2 and 955.1 liters of water will be used to produce the forage and hay-based products needed to generate one $\mathrm{kg}$ of red meat, reducing the blue water requirement from $2,095.0 \mathrm{~L} \mathrm{~kg}^{-1} \mathrm{CW}$ to between 264.1 and $1,018.0 \mathrm{~L} \mathrm{~kg}^{-1} \mathrm{CW}$.

\section{Impacts From Agricultural Ammonia $\left(\mathrm{NH}_{3}\right)$ Emissions}

Ammonia emissions contribute to eutrophication and acidification in aquatic ecosystems, vegetation damage and alteration of plant community composition in terrestrial ecosystems, and human morbidity (Kelly et al., 2005). Agriculture is a significant ammonia source. For instance, $\sim 80-94 \%$ of all $\mathrm{NH}_{3}$ emissions in Europe and the United States are thought to be contributed by agricultural activities (Webb et al., 2005; Herbert et al., 2020). Agricultural emissions in the United Kingdom were estimated to be $228 \mathrm{kt}-\mathrm{N}$ at the turn of the twenty-first century (Pain et al., 1998; Sutton et al., 2000). Animal agricultural emissions [1.67 mtons $\mathrm{y}^{-1}$ in the US (USEPA (U.S. Environmental Protection Agency), 2016)] are generated by animal housing and confinement practices, manure storage and slurry spreading, inorganic fertilizer use, 
and grazing. Together, housing and confinement practices, manure spreading, and fertilizer use account for about $75 \%$ of all emissions. The ammonia contribution associated with grazing is relatively minor, about 12\% (Misselbrook, 2015).

I am not aware of studies comparing the magnitudes of ammonia emissions and impacts on farms employing RM practices with those produced by IC operations. It seems reasonable, however, to hypothesize that IC agriculture creates a substantially larger ammonia footprint than RM agriculture due to intensive confinement and other practices. Further research in this area seems warranted.

\section{Impacts Associated With Climate Change}

Agriculture is a significant source of greenhouse gas (GHG) emissions. Three factors determine the net agricultural contribution: (i) $\mathrm{CO}_{2}$-eq emitted; (ii) $\mathrm{CO}_{2}$-eq removed and (iii) $\mathrm{CO}_{2}$-eq stored in the soil.

\section{$\mathrm{CO}_{2}$-eq Emitted}

Farming, forestry, and land use change associated with agriculture contribute $24-31 \%$ of the 50.9 GT of annual global GHG emissions (IPCC, 2014). Nearly half of this is the result of rainforest destruction, much of it for livestock grazing and feed-grain production (IPCC, 2018). In aggregate, livestock production represents $14.5 \%$ (7.1 GT) of total GHG emissions globally (Olivier and Peters, 2018; Food Agriculture Organization, 2020). Feed production (including the soils used to grow feed crops), i.e., the cultivation of grains used for livestock feeds, usually in large monocultures produced with the use of synthetic fertilizers and pesticides, is the largest GHG contributor within animal agriculture. Feed production accounts for $\sim 45 \%$ (3.2 GT) of total GHG emissions within the category. This is followed by enteric (principally methane) production (39\%), manure management (10\%), and transportation and processing $(6 \%)$.

In 2017 , agriculture contributed $\sim 9.1 \%$ of the $6.5 \mathrm{GT}$ of $\mathrm{CO}_{2}$ eq emitted in the United States [USEPA (U.S. Environmental Protection Agency), 2016]. Crop production (including that required for livestock feeds) contributed about 58\% (3.77 GT) of total US agricultural GHG emissions. Livestock production contributed 42\% (2.73 GT). Rotz et al. (2019) provide a breakdown of the source-terms: Enteric GHG production, principally as methane, contributes $56 \%$ of livestock-based $\mathrm{CO}_{2}$ eq; pasture, range and crop lands emit $24 \%$ of all $\mathrm{CO}_{2}$-eq (mostly as $\mathrm{N}_{2} \mathrm{O}$ ). Manure contributes slightly $<20 \%$ of $\mathrm{CO}_{2}$-eq- $-10 \%$ as $\mathrm{CH}_{4}$ and $<10 \%$ as $\mathrm{N}_{2} 0$. Fertilizer, electricity, fuel production and other upstream sources contribute $13 \%$ and fuel combustion and lime decomposition contribute $4 \%$.

The values presented above on do not distinguish among livestock management practices and would therefore be assumed to be skewed toward emissions arising from conventional grazing and IC practices that dominate animal agriculture. Given the growing interest in regenerative agriculture, however, it seems reasonable to attempt a comparison of GHG emissions from RM and IC livestock production practices (Table 2). By obviating the GHG emissions associated with feed-grain production, emissions are reduced by $\sim 59 \%$. While enteric methane production by
TABLE 2 | Greenhouse gas emissions (as GT CO $2-e q ~ y^{-1}$ ) associated with livestock production by industrial-conventional (IC) and regenerative-multi-paddock (RM) practices.

\begin{tabular}{lcc}
\hline & \multicolumn{3}{c}{ GHG from management approach } \\
\cline { 2 - 3 } & $\mathbf{I C}$ & $\mathbf{R M}$ \\
& $\mathbf{C O}_{\mathbf{2}}$-eq $\left(\mathbf{G T} \mathbf{~ y}^{-\mathbf{1}}\right)$ & $\mathbf{C O}_{\mathbf{2}}$-eq $\left(\mathbf{G T} \mathbf{~}^{\mathbf{- 1}}\right)$ \\
\hline Feed production & 3.2 & $1.3^{\mathrm{a}}$ \\
Enteric processing & 2.8 & $2.7^{\mathrm{b}}$ \\
Manure management & 0.7 & $0.3^{\mathrm{c}}$ \\
Transportation and energy & 0.4 & $0.3^{\mathrm{d}}$ \\
\hline Total & 7.1 & 4.6
\end{tabular}

Data for (globally dominant) IC practice are from Food Agriculture Organization (2019). Estimates for RM management reflect recalculation of emissions from each category based on studies comparing IC and RM (or organic) practices.

${ }^{a}$ Reflects removal of grain production and production of synthetic inputs derived from the use factors of Rotz et al. (2019).

${ }^{b}$ Reflects a 20\% increase in GHG emissions assuming a grass-based, rather than a grassgrain based diet, and a 22\% decrease in GHG emissions from multi-paddock rotational practices (DeRamus et al., 2003).

${ }^{c}$ Based on the mean difference (56.3\%) in $\mathrm{CH}_{4}$ and $\mathrm{N}_{2} \mathrm{O}$ emissions associated with manure management and distribution practices on conventional and regenerative (organic) farms. Sources: Chadwick (2011), Sneath et al. (2006), Weiske et al. (2006), and Yamulki (2006).

${ }^{d}$ Reflects a $28 \%$ reduction in GHG emissions by using RM (organic) practices (Pimentel et al., 2006).

"grass-fed" cattle will be as much as $20 \%$ higher than by grainfed animals, the use of frequent pasture rotations reduces enteric methane production by, on average, 22\% (DeRamus et al., 2003). Although manure management practices vary widely in both IC and RM systems, a review of several sources (see notes below Table 2) suggests an average estimated difference of $56.3 \%( \pm$ standard deviation $=45.2$ ) between IC and RM operations. Transportation and energy inputs (oil and fuel) were estimated to be $28 \%$ lower for RM animal agriculture than for IC agriculture (Pimentel et al., 2006). Applying these changes, RM management appears capable of reducing annual global GHG emissions from livestock production by $\sim 35.2 \%$, to $4.6 \mathrm{GT} \mathrm{CO}_{2}$-eq $\mathrm{y}^{-1}$. Estimates by Havlik et al. (2014) suggest that changes from conventional to RM practices would lower GHG emissions by about 3.2 $\mathrm{GT} \mathrm{CO}_{2}$-eq $\mathrm{y}^{-1}$, consistent with the estimate presented in Table 2. The effect of forage quality on GHG emissions is not captured in Table 2, but improvements in forage quality would be expected to lower enteric methane production further (Beauchemin et al., 2008; Herrero et al., 2013).

\section{$\mathrm{CO}_{2}$-eq Removed}

Grasslands play a critical role in photosynthetic carbon sequestration (Derner and Schuman, 2007; Sacks et al., 2014). Net terrestrial primary productivity (NPP), on the order of 56.462.1 GT $\mathrm{yr}^{-1}$, constitutes just over half of the annual global production (Foley, 1994; Field et al., 1998). Tropical rainforests $\left(17.8 \mathrm{GT} \mathrm{yr}^{-1}\right)$ and savannahs + perennial grasslands (19.2 GT $\mathrm{yr}^{-1}$ ) account for 60-65 percent of the total.

Stanley et al. (2018) used a life cycle assessment (LCA) to investigate the path of carbon through multi-paddock and 
conventional beef cattle finishing systems in the American mid-west. Their study revealed significantly higher net GHG production by MP than by conventional practices, due to a $>2.5$-fold higher enteric GHG emission rate from MP systems than from conventional, grain-based systems. Furthermore, over the life cycle of production, GHG emissions from MP systems were 1.6 times higher than that from conventional management when carbon flux into the soil (i.e., sequestration) was not considered. However, when sequestration was included in the assessment, the MP model significantly out-performed the conventional model, removing more than twice the $\mathrm{CO}_{2}$ eq of conventional beef production. LCA studies by Pelletier et al. (2010) and Lupo et al. (2013) support these observations, suggesting a $24-30 \%$ reduction in net GHG production as a function of sequestration from grass-fed beef production. These observations are consistent with an LCA analysis by Wang et al. (2015) for beef production in Texas, and they track well with empirical observations (Teague et al., 2011; Dowhower et al., 2019; Rowntree et al., 2019). The importance of C-sequestration by grasslands is clearly critical to the efficacy of agriculture as a vehicle for GHG removal. As such, MP practices may prove to be a valuable tool for climate change mitigation. As Lal (2019) states,

"The technical potential of carbon sequestration in world soils may be 2 billion to 3 billion $m$ t per year for the next 50 years. The potential of carbon sequestration in soils and vegetation together is equivalent to a draw-down of about 50 parts per million of atmospheric CO2 by 2100."

\section{$\mathrm{CO}_{2}$-eq Stored in the Soil}

Grassland and agricultural soils, which cover 53.6\% of the earth's land area, store between 52 and $55 \%$ of the net terrestrial primary production (Sacks et al., 2014). Turnover of aboveground primary production by aerobic decomposition occurs on timescales of seasons. Herbivorous conversion of plant biomass to dung and urine increases turnover efficiency by 21\% (Yoshitake et al., 2014), and facilitates development of soil microbial community structure, which in turn promotes the stabilization and storage of carbon in the soil (Merrill et al., 1994; Bardgett et al., 1998). Patchy deposition of dung, as occurs when livestock densities are low, is obviated by MP practices that manage at higher stock densities and rotation frequencies (Gerrish, 2004; Flack, 2016).

Integration of livestock and crop production may offer additional opportunities to mitigate GHG emissions ( $\mathrm{Liu} \mathrm{H}$. et al., 2015; Lal, 2020). Conservation agriculture (CA), described by Lal (2004, 2015, 2019), focuses on increasing carbon storage in the soil during crop production. CA practice involves a commitment to minimal disruption of the soil surface (e.g., low-till or no-till planting), and to ensuring that the soil is always covered with forage, cover crops, or harvest tailings. CA also encourages diversification of vegetation and crop rotation (Farooq and Siddique, 2014). One can speculate that when overlaid on the CA framework, the integration of high frequency rotations of densely stocked ruminants through a rotational cycle that includes harvested crop fields, followed by prolonged rest, would enhance carbon sequestration and storage in croplands

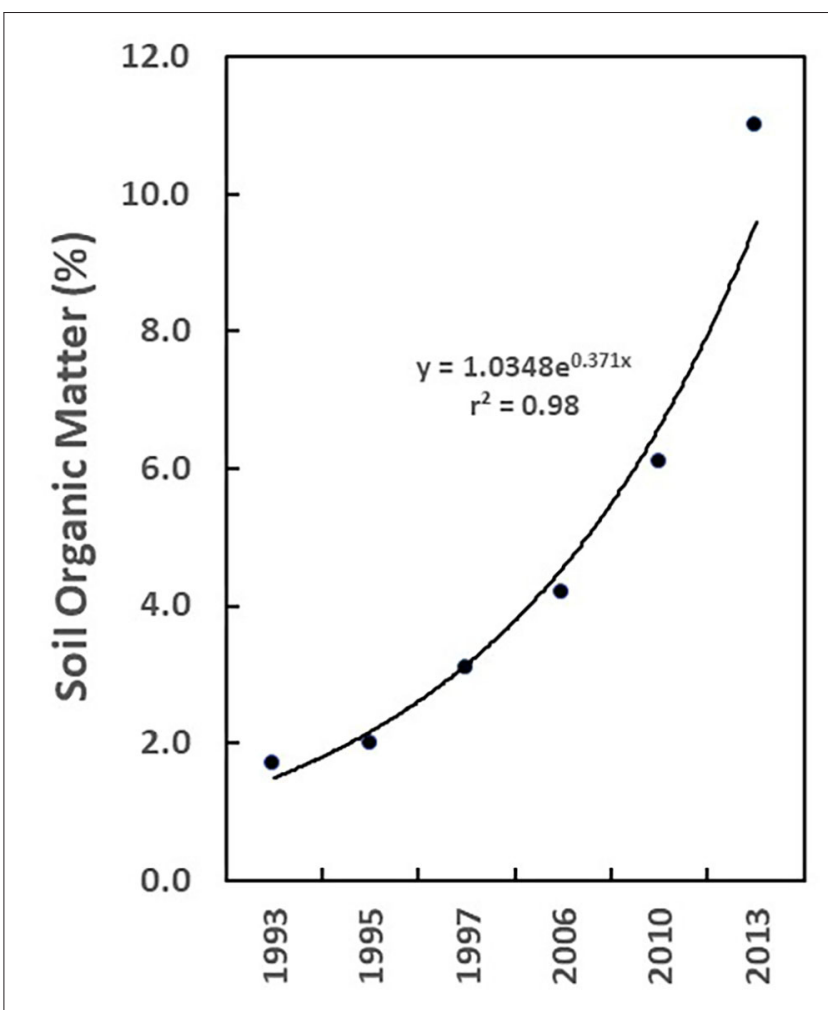

FIGURE 1 | Soil organic matter (SOM; \%) at Brown Ranch, near Bismarck, North Dakota, USA, 1993-2013 (source of data: Brown, 2016).

while improving fertility. In a case study described in the popular media, Brown $(2016,2018)$ tracked the deposition of carbon into the soil of his 2000 ha ranch near Bismarck, North Dakota, USA over 23 years. The ranch is managed by integrating RM livestock practices with the principles of conservation agriculture to produce beef cattle, sheep, chickens and a variety of crops. During the course of Brown's analysis, soil organic matter on his ranch increased more than 5-fold, from 1.7 to $11.0 \%$ (Figure 1).

To summarize, it would appear that MP and RM practices are capable of making significant contributions to climate change mitigation. GHG emissions can be reduced by more than 30\%, C-sequestration can be increased by $24-30 \%$ (and possibly considerably more), and the time required to convert photosynthetically fixed carbon, i.e., plant biomass, into stable carbon in the soil can be reduced by $21 \%$ through grazing, relative to the time required for oxidative turnover. By applying the reduction in GHG emissions via C-sequestration to the estimated emissions from RM practices in Table 2, the net GHG contribution by animal agriculture would be 3.2-3.5 $\mathrm{GT} \mathrm{CO}_{2}$ eq $\mathrm{y}^{-1}$ or, conservatively, $45.1-49.3 \%$ (i.e., removal of more than half) of current emissions.

These estimates support the conclusion that agriculture has a critical role to play in the removal of carbon from the atmosphere and in the stabilization and storage of carbon in the soil (Food Agriculture Organization, 2019).

Sacks et al. (2014) go further, suggesting that well-managed grazing in arid and semi-arid regions, where severe soil 
degradation and desertification have occurred, can play a pivotal role in carbon sequestration and climate change mitigation:

\begin{abstract}
This approach... Holistic Planned Grazing, the effectiveness of which has been demonstrated on over millions of hectares on four continents... has the potential to remove excess atmospheric carbon resulting from anthropogenic soil loss over the past 10,000 years and... all industrial-era greenhouse gas emissions. This sequestration potential...could, in theory, return 10 or more gigatons of... atmospheric carbon to the terrestrial sink annually and lower greenhouse gas concentrations to pre-industrial levels in a matter of decades..."
\end{abstract}

Clearly, the possibility of a pasture-based approach to planetary carbon management is worthy of further consideration.

\section{DISCUSSION}

From this brief review, it is evident that significant differences exist between the impacts of IC and RM management with respect to key ecosystem attributes. Though the issue is far from resolved, RM practices appear in many respects to be environmentally benign relative to their IC counterparts. The environmental impacts considered here, and the differences between the management practices that create them may not be the direct result of livestock activities on pasture or rangeland. Often, they are due to differences in the resource intensities (e.g., water or fossil fuels) required to support IC or RM management.

Papers published between the 1980s and the present have repeatedly questioned the efficacy of various forms of MP management, particularly Savory and Butterworth's $(1999,2016)$ holistic approach (e.g., Holechek et al., 2000; Briske et al., 2008; Hawkins et al., 2017; and others). Some of the hypotheses and observations promoted by Savory, such as the ability of holistic management to mitigate desertification and climate change (Savory, 2013) have been particularly contentious (Briske et al., 2013). However, Teague et al. (2009, 2013), Wang et al. (2016), and others (e.g., see Teague, 2014) have pointed to the technical and scaling issues that may influence the interpretation of the reductionist approaches typical of traditional experimental comparisons of livestock performance and their environmental consequences under IC management. It has also been suggested that contradictory results may accrue, at least in part, from perceptual differences in the management and operational goals of RM and IC management by both researchers and graziers (Briske et al., 2011). The contentiousness of the debate may contribute to its apparent un-resolvability (Collins, 1981). Briske et al. (2011) suggest moving beyond the debate over whether one management approach is better than the other. They suggest that the focus should be on finding adaptive approaches to livestock production and pasture/rangeland management that respond to the realities of meat production. Sherren and Kent (2019) decry the "linear" (i.e., reductionist) thinking that dominates the issue. The capacity of scientists to deal effectively with complex systems has long been problematic (Capra, 2005). Grazing ecosystems and the outcomes of herbivore-plant-soil interactions, while seemingly simple, are actually functionally complex (Liu J. et al.,
2015). Sherren and Kent (2019) and Wynne (1992) point out that frequently researchers exclude or simply miss the realities of livestock management as experienced by graziers. Briske et al. (2011) and Gosnell et al. (2020) suggest incorporating multi-dimensional, socio-ecological perspectives into efforts to understand livestock management dynamics and its outcomes.

Traditionally, livestock farming, and ranching have had an overriding purpose: production (Toombs and Roberts, 2009). The determination of how to produce the greatest weight gain in the shortest amount of time is of interest to all farmers, ranchers, and students of animal science. Comparisons of livestock weight gain in MP and conventional grazing systems have not been consistent, and more than likely depend upon interactions among stocking rates, forage compositions and any number of highly variable environmental forcing functions as well as the spatial scales at which observations are made (Derner and Hart, 2007; also see Teague et al., 2013 for more detailed treatment of this subject).

Notwithstanding the importance of production, the slow but persistent emergence of the organic, sustainable, and regenerative farming movements have made environmental stewardship an additional, and even principal goal of animal agriculture. The practitioner's approach toward livestock management broadens when the focus of one's work includes land stewardship. Livestock is no longer the sole product. In fact, livestock becomes a tool to be used in the regenerative process. The convergent goalsproduction and stewardship-are not necessarily complementary and achieving one goal may impede achievement of the other, at least temporarily. For example, cattle produced by RM management often require 3-6 months longer to finish than grain-supplemented, pastured, or feedlot-finished cattle. However, RM practice may provide positive outcomes by improving soil health and forage quality, and by mitigating a substantial portion of total global GHG emissions.

It is common knowledge among both farmers and researchers that soil loss and grassland degradation are at near crisis stage (Pimentel, 1997, 2006; Montgomery, 2017; Brown, 2018; J. Kempf, pers. comm. 2017). It is not simply appropriate, but necessary, to the future of agriculture, that some of our attention be focused on soil and ecosystem regeneration. When one manages for soil health, water quality, GHG mitigation, biodiversity, and the restoration of other essential ecosystem services, as well as for livestock production, even the most fundamental management decisions will likely differ from those made when production is the only focus of one's practice. Consistent with the advice of Briske et al. (2011) and Gosnell et al. (2020), we must recognize that complex issues have only partial solutions in science, and that fuller and more satisfying solutions accrue by integrating scientific and practical knowledge (Sherren and Kent, 2019).

\section{CONCLUSION}

It is worth remembering that agriculture provides $98 \%$ of the food that humans consume, and that meat is critical to the global food supply (White and Hall, 2017). Two thirds of the land on 
which food is produced can only be used for meat production. If nothing else, this review has supported the concern of many that agriculture is the cause of significant environmental pollution, ecosystem stress, habitat destruction and the loss of ecosystem services. This must change; meat production must and can become a vehicle for creating protein sufficiency, environment integrity and the restoration of ecosystem services, globally. It is the very definition of a non-sequitur that: while food is a critical part of our life support system, to produce food we must destroy our life support system.

The results of the present analysis suggest that producing livestock need not destroy our life support system. RM practices, with their focus on the restoration and enhancement of ecosystems and the critical services they provide, appear to have the potential to make meat production a more environmentally benign process. Clearly, much is unknown. Data gaps remain; improvements in practice are needed and, in some cases, forthcoming. Supply chain models to ensure the economic viability of $\mathrm{RM}$ livestock production at scale are, at best, in the early stages of development. Adoption by farmers and ranchers remains limited, and policies and educational programs that encourage greater participation in RM practice are often lacking or poorly advertised (Francis et al., 1986). Efforts to discourage regenerative meat production by special interests and naivete within certain sectors of the research community have slowed development of sustainable meat production practices (e.g., Willett et al., 2019). Yet, given that meat consumption is increasing worldwide (NAS, 2015), adoption of environmentally regenerative meat production practices seems crucial.

Although enough food is currently produced to provide a calorically sufficient daily ration to every human being on earth, we are rapidly approaching carrying capacity (Cribb, 2010; Tilman et al., 2011). Within the next 30 years, as the human population approaches 10 billion, as the climate becomes increasingly hostile, as water, soil, biodiversity, and other resources disappear, it will become increasingly difficult to feed ourselves (Larson et al., 1983; Pimentel et al., 1992; IPCC, 2019). Although regenerative production will not slow population growth and will never, in and of itself, provide the solution to world hunger, agriculture, including animal agriculture, can play an important role in GHG mitigation, soil-health restoration, and water and biodiversity conservation (Lal, 2004; Herrero and Thornton, 2013; Sacks et al., 2014; Cassidy and Kleppel, 2017; Montgomery, 2017; Stanley et al., 2018). The effectiveness of agriculture as a tool, not only for feeding ourselves but for meeting the challenges posed by human population growth, and in the process providing a sustainable income to farmers and

\section{REFERENCES}

Abdel-Magid, A. H., Schuman, G. E., and Hart, R. H. (1987). Soil bulk density and water infiltration as affected by grazing systems. J. Range Manag. 40, 307-309. doi: $10.2307 / 3898725$

Acocks, J. P. H. (1966a). Non-selective grazing as a means of veld reclamation. Proc. Grassland Soc. South. Afr. 1, 33-39. doi: 10.1080/00725560.1966.9648517 ranchers has been suggested by research and demonstrated in practice (Food Agriculture Organization, 2013; Kleppel, 2014; Teague and Barnes, 2017; Brown, 2018; Massy, 2018; Amadu et al., 2020). Livestock production represents a tool, not only for providing calories and protein to our species over the next half century, but for ensuring the livability of our planet to humans and myriad other species well into the future.

\section{AUTHOR'S NOTE}

Ungulates are key to human nutrition and the functioning of Earth's ecosystems. Nonetheless, animal agriculture is a significant contributor to grassland degradation and soil destruction, water pollution and depletion, and global greenhouse gas emissions. It seems a non-sequitur that the production of food, part of our life support system, should be linked to degradation of the environment (i.e., our life support system). I reviewed the literature on two approaches to livestock management, one based on industrial agriculture, the other on regenerative agriculture, to ascertain whether one system is environmentally benign relative to the other. There is a lack of consensus on which approach is less destructive of plant communities or soil structure, though regenerative management appears to support larger, more diverse soil microbial communities. Furthermore, regenerative animal agriculture appears less likely to contribute to water pollution, to have lower water withdrawal requirements, and to be associated with lower greenhouse gas emissions and higher greenhouse gas removal rates than industrial management. By broadening the focus of animal agriculture to include both production and stewardship we can feed our species while reducing damage to the environment.

\section{AUTHOR CONTRIBUTIONS}

The author confirms being the sole contributor of this work and has approved it for publication.

\section{FUNDING}

Internal funding from the University at Albany, SUNY.

\section{ACKNOWLEDGMENTS}

I am grateful to F. D. Provenza for many useful conversations and for comments on an earlier draft of the manuscript. 
Alkemade, R., Reid, R. S., van den Berg, M., de Leeuw, J., and Jeuken, M. (2013). Assessing the impacts of livestock production on biodiversity in rangeland ecosystems. Proc. Natl. Acad. Sci. U.S.A. 110, 20900-20905. doi: 10.1073/pnas.1011013108

Allen, L. J. S., Allen, E. J., Kunst, C. R. G., and Sosebee, R. E. (1991). A diffusion model for dispersal of Opuntia Imbricata (Cholla) on rangeland. J. Ecol. 79, 1123-1135. doi: $10.2307 / 2261103$

Amadu, F. O., Miller, D. C., and McNamara, P. E. (2020). Agroforestry as a pathway to agricultural yield impacts in climate-smart agriculture investments: evidence from southern Malawi. Ecol. Econ. 167:106443. doi: 10.1016/j.ecolecon.2019.106443

Archibald, S. (2008). African grazing lawns: How fire, rainfall, and grazer numbers interact to affect grass community states. J. Wildl. Manage. 72, 492-501. doi: $10.2193 / 2007-045$

Badgery, W. S. (2017). Longer rest periods for intensive rotational grazing limit diet quality of sheep without enhancing environmental benefits. Afr. J. Range Forage Sci. 34, 99-109. doi: 10.2989/10220119.2017.1329752

Balfour, E. (1943). The Living Soil. London: Faber and Faber.

Baltica, M. Z., and Boskovica, M. (2015). When man met meat: meat in human nutrition from ancient times till today. Proc. Food Sci. 5, 6-9. doi: 10.1016/j.profoo.2015.09.002

Bardgett, R. D., Jones, A. C., Jones, D. L., Kemmitt, S. J., Cook, R., and Hobbs, P. J. (2001). Soil microbial community patterns related to the history and intensity of grazing in sub-montane ecosystems. Soil Biol. Biochem. 33, 1653-1664. doi: 10.1016/S0038-0717(01)00086-4

Bardgett, R. D., and Leemans, D. K. (1995). The short-term effects of cessation of fertiliser applications, liming, and grazing on microbial biomass and activity in a reseeded upland grassland soil. Biol. Fert. Soils 19, 148-154. doi: 10.1007/BF00336151

Bardgett, R. D., Leemans, D. K., Cook, R., and Hobbs, P. J. (1997). Seasonality of soil biota of grazed and ungrazed hill grasslands. Soil Biol. Biochem. 29, 1285-1294. doi: 10.1016/S0038-0717(97)00019-9

Bardgett, R. D., Wardle, D. A., and Yeates, G. W. (1998). Linking aboveground and below-ground interactions: how plant responses to foliar herbivory influence soil organisms. Soil Biol. Biochem. 30, 1867-1878. doi: 10.1016/S0038-0717(98)00069-8

Barnes, D. L., and Denny, R. P. (1991). A comparison of continuous and rotational grazing on veld at two stocking rates. J. Grassland Soc. South Afr. 8, 168-173. doi: 10.1080/02566702.1991.9648285

Beauchemin, K. A., Kreuzer, M., O’Mara, F., and McAllister, T. A. (2008). Nutritional management for enteric methane abatement: a review. Aust. J. Exp. Agric. 48, 21-27. doi: 10.1071/EA07199

Bellis, M. (2018). History of American Agriculture. Available online at: https://www. thoughtco.com/history-of-american-agriculture-farm-machinery- 4074385 (accessed March 20, 2020).

Belsky, A. J. (1987). The effects of grazing: confounding of ecosystem, community and organism scales. Am Nat. 129, 777-783. doi: 10.1086/284674

Bishopp, T. (2020). How a Grazing Plan Prevented a Wreck. On Pasture. Available online at: https://onpasture.com/2020/01/13/how-a-grazing-plan-preventeda-wreck/ (accessed March 21, 2020).

Booysen, P., and De, V. (1969). An analysis of the fundamentals of grazing management systems. Proc. Ann. Congr. Grassland Soc. South. Afr. 4, 84-91. doi: 10.1080/00725560.1969.9648593

Borlaug, N. E. (1970). Nobel Lecture: The Green Revolution, Peace, and Humanity. Noble Peace Prize, Oslo.

Borlaug, N. E. (2002). Feeding a world of 10 billion people: the miracle ahead. In Vitro Cell. Dev. Biol. Plant 38, 221-228. doi: 10.1079/IVP2001279

Bouma, J. (2002). Land quality indicators of sustainable land management across scales. Agric. Ecosyst. Environ. 88, 129-136. doi: 10.1016/S0167-8809(01)00248-1

Briske, D. D., Bestelmeyer, B. T., Brown, J. R., Fuhlendorf, S. D., and Polley, H. W. (2013). The Savory method cannot green deserts or reverse climate change. Rangelands 35, 72-74. doi: 10.2111/RANGELANDS-D-1300044.1

Briske, D. D., Derner, J. D., Brown, J. R., Fuhlendorf, S. D., Teague, W. R., Havstad, K. M., et al. (2008). Rotational grazing on rangelands: reconciliation of perception and experimental evidence. Rangeland Ecol. Manage. 61, 3-17. doi: 10.2111/06-159R.1
Briske, D. D., Sayre, N. F., Huntsinger, L., Fernandez-Gimenez, M., Budd, B., et al. (2011). Origin, persistence, and resolution of the rotational grazing debate: Integrating human dimensions into rangeland research. Rangeland Ecol. Manag. 64, 325-334. doi: 10.2111/REM-D-10-00084.1

Brown, G. (2016). The Regeneration of Our Lands: A Producer's Perspective. TEDXGrand Forks, ND. Available online at: https://www.youtube.com/watch? time_continue $=6 \mathrm{andv}=\mathrm{QfTZ}$ _ rnowccandfeature $=\mathrm{emb}$ _title (accessed March 18, 2020).

Brown, G. (2018). Dirt to Soil. White Water Junction, VT: Chelsea Green, 240.

Brown, L. R. (1970). The social impact of the green revolution. Int. Concil 3, 5-45.

Capra, F. (2005). Complexity and life. Emergence 4, 15-33. doi: 10.1207/S15327000EM04landamp;2-03

Cassidy, L. R., and Kleppel, G. S. (2017). The effect of grazing regime on grassland bird abundance in New York State. Northeastern Nat. 24, 86-98. doi: 10.1656/045.024.0sp807

Chadwick, D., Sommer, S., Thorman, R., Fangueiroe, D., Cardenas, L., Amon, B. et al. (2011). Manure management: implications for greenhouse gas emissions. Anim. Feed Sci. Tech. 166-167, 514-531. doi: 10.1016/j.anifeedsci.2011.04.036

Cingolani, A. M., Noy-Meir, I., and Díaz, S. (2005). Grazing effects on rangeland diversity: a synthesis of contemporary models. Ecol. Appl. 15, 757-773. doi: 10.1890/03-5272

Collins, H. (1981).'Son of seven sexes': the social destruction of a physical phenomenon. Soc. Stud. Sci. 11, 33-62. doi: 10.1177/030631278101100103

Cribb, J. (2010). The Coming Famine. Berkeley, CA: University of California. doi: $10.1525 / 9780520947160$

Crosson, P., Pimentel, D., Harvey, C., Resosudarno, P., Sinclair, K., and Kurz, D. (1995). Soil erosion estimates and costs. Science 269, 461-465. doi: $10.1126 /$ science.269.5223.461

Daubenmire, R. F. (1940). Plant succession due to overgrazing in the Agropyron Bunchgrass prairie of Southeastern Washington. Ecology 21, 55-64. doi: $10.2307 / 1930618$

DeRamus, H. A., Clement, T. C., Giampola, D. D., and Dickison, P. C. (2003). Methane emissions of beef cattle on forages: efficiency of grazing management systems. J. Environ. Qual. 32, 269-277. doi: 10.2134/jeq2003.2690

Derner, J. D., and Hart, R. H. (2007). Grazing-induced modifications to peak standing crop in northern mixed-grass prairie. Rangeland Ecol. Manag. 60, 270-276. doi: 10.2111/1551-5028(2007)60[270:GMTPSC]2.0.CO;2

Derner, J. D., and Schuman, G. E. (2007). Carbon Sequestration and Rangelands: A Synthesis of Land Management and Precipitation Effects. Journal of Soil and Water Conservation, 62. Available online at: https://link-gale-com.libproxy. albany.edu/apps/doc/A163390875/AONE?u=albanyuandsid=AONEandxid= cc86e00c (accessed March 18, 2020).

Doran, J. W. (2002). Soil health and global sustainability: translating science into practice. Agric. Ecosyst. Environ. 88, 119-127. doi: 10.1016/S0167-8809(01)00246-8

Doran, J. W., Stamatiadis, S. I., and Haberern, J. (2002). Soil health as an indicator of sustainable management. Agric. Ecosyst. Environ. 88, 107-110. doi: 10.1016/S0167-8809(01)00250-X

Dowhower, S. L.,Teague, W. R., Casey, K. D., and Daniel, R. (2019). Soil greenhouse gas emissions as impacted by soil moisture and temperature under continuous and holistic planned grazing in native tallgrass prairie. Agric. Ecosyst. Environ. 286:106647. doi: 10.1016/j.agee.2019.106647

Drewry, J. J. (2006). Natural recovery of soil physical properties from treading damage of pastoral soils in new zealand and australia: a review. Agric. Ecosyst. Environ. 114, 159-169. doi: 10.1016/j.agee.2005.11.028

Ebner, P. (2017). CAFOs and Public Health: Pathogens and Manure. Technical Paper ID-356. West Lafayette, IN, Purdue Extension, Purdue University.

Farooq, M., and Siddique, K. H. M. (2014). Conservation Agriculture. Heidelberg: Springer International.

FDA (U.S. Food and Drug Administration) (2013). Phasing Out Certain Antibiotic Use in Farm Animals. Available online at: https://www.fda.gov/ consumers/consumer-updates/phasing-out-certain-antibiotic-use-farmanimals (accessed March 18, 2020)

FDA (U.S. Food and Drug Administration). (2019). Antimicrobial Resistance. Available online at: https:/www.fda.gov/animal-veterinary/safety-health/ antimicrobial-resistance (accessed March 18, 2020).

Feingold, B. J., Silbergeld, E. K., Curriero, F. C., van Cleef, B. A. G. L., Heck, M. E. O. C., and Kluytmans, J. A. J. W. (2012). Livestock density as risk 
factor for livestock-associated Methicillin-resistant Staphylococcus aureus, the Netherlands. Emerg. Infect. Dis. 18, 1141-1149. doi: 10.3201/eid1811.111850

Field, C. B., Behrenfeld, M. J., Randerson, J. T., and Falkowski, P. (1998). Primary production of the biosphere: Integrating terrestrial and oceanic components. Science 281, 236-240. doi: 10.1126/science.281.5374.237

Flack, S. (2016). The Art and Science of Grazing. White River Junction, VT: Chelsea Green, 230.

Foley, J. A. (1994). Net primary productivity in the terrestrial biosphere: the application of a global model. J. Geophys. Res. Atmos. 99, 20773-20783.

Food and Agriculture Organization (2013). Tackling Climate Change Through Livestock. Rome: Food and Agriculture Organization of the United Nations, 115.

Food and Agriculture Organization (2019). "FAO's work on climate change," in United Nations Conference on Climate Change, 2019 (Rome: Food and Agriculture Organization of the United Nations), 38.

Food and Agriculture Organization (2020). The Contribution of Agriculture to Greenhouse Gas Emissions. Rome: Food and Agriculture Organization of the United Nations.

Francis, C. A., Harwood, R. R., and Parr, J. F. (1986). The potential for regenerative agriculture in the developing world. Am. J. Alter. Agric. 1, 65-74. doi: $10.1017 /$ S0889189300000904

Frank, D. A. (2005). The interactive effects of grazing ungulates and aboveground production on grassland diversity. Oecologia 143, 629-634. doi: 10.1007/s00442-005-0019-2

Frank, D. A., Groffman, P. M., Evans, R. D., and Tracy, B. F. (2000). Ungulate stimulation of nitrogen cycling in yellowstone park grasslands. Oecologia 123, 116-123. doi: 10.1007/s004420050996

Frank, D. A., McNaughton, S. J., and Tracy, B. F. (1998). The ecology of the earth's grazing ecosystems. BioScience 48, 513-521. doi: 10.2307/1313313

Franzluebbers, A. J., and Stuedemann, J. A., Franklin, D. H. (2012). Water infiltration and surface-soil structural properties as influenced by animal traffic in the Southern Piedmont USA. Renew. Agric. Food Syst. 27, 256-265. doi: $10.1017 /$ S1742170511000378

Gerrish, J. (2004). Management Intensive Grazing. Greeley, CO: Acres, USA, 315.

Girard Cartier, C. B. (2017). Grazing and the coupling of vascular plant and soil microbial diversity in agricultural landscapes of eastern New York (dissertation). State University of New York, Albany, NY.

Girard Cartier, C. B., and Kleppel, G. S. (2015). Grazing as a control for the spread of mile-a-minute (Persicaria perfoliata) and the restoration of biodiversity in plant communities in a lower New York State parkland. Ecol. Restor. 33, 82-89. doi: 10.3368/er.33.1.82

Girard Cartier, C. B., and Kleppel, G. S. (2017). Grazing and the coupling of biodiversity in the vascular plant and soil microbial communities. special issue on the natural history of agricultural landscapes. Northeastern Nat. 24, 67-85. doi: $10.1656 / 045.024 .0 \mathrm{sp} 806$

Goodloe, S. (1969). Short-duration grazing in rhodesia. J. Range Manag. 22, 369-373. doi: $10.2307 / 3895844$

Gosnell, H., Grimm, K., and Goldstein, B. E. (2020). A half century of holistic management: what does the evidence reveal? Agric. Hum. Val. 37, 849-867. doi: 10.1007/s10460-020-10016-w

Harrison, K. A., and Bardgett, R. D. (2010). "Impacts of grazing and browsing by large herbivores on soils and soil biological properties," in The Ecology of Browsing and Grazing, eds I. J. Gordon and H. H. T. Prins (Berlin: Springer), 201-216. doi: 10.1007/978-3-540-72422-3_8

Havlik, P., Valin, H., Herrero, M., Obersteiner, M., Schmid, E., Rufino, M. C., et al. (2014). Climate change mitigation through livestock system transitions. Proc. Natl. Acad. Sci. U.S.A. 111, 3709-3714. doi: 10.1073/pnas.1308044111

Hawkins, H.-J., Short, A., and Kirkman, K. P. (2017). Does holistic planned grazing work on native rangelands? Afr. J. Range Forage Sci. 34, 59-63. doi: $10.2989 / 10220119.2017 .1367328$

Hayes, G. F., and Holl, K. D. (2003). Cattle grazing impacts on annual forbs and vegetation composition of mesic grasslands in california. Conserv. Biol. 17, 1694-1702. doi: 10.1111/j.1523-1739.2003.00281.x

Herbert, S., Hashemi, M., Chickering-Sears, C., and Weis, S. (2020). Conserving Ammonia In Manure. CDLE Pub. 09-50. UMass Extension Service. Amherst, MA: University of Massachusetts.

Herrero, M., Havlik, P., Valin, H., Notenbaert, A., Rofino, M. C., and Thornton, P. K. (2013). Biomass use, production, feed efficiencies, and greenhouse gas emissions from global livestock systems. Proc. Natl. Acad. Sci. U.S.A. 110, 20888-20893. doi: 10.1073/pnas.1308149110

Herrero, M., and Thornton, P. K. (2013). Livestock and global change: emerging issues for sustainable food systems. Proc. Natl. Acad. Sci. U.S.A. 110, 20878-20881. doi: 10.1073/pnas.1321844111

Hilario, M. C., Wrange-Monnig, N., and Isselstein, J. (2017). Behavioral patterns of (co-)grazing cattle and sheep on swards differing in plant diversity. Appl. Anim. Behav. Sci. 191, 17-23. doi: 10.1016/j.applanim.2017.02.009

Hoffman, M. T. (2003). 'Nature's method of grazing': Non-Selective Grazing (NSG) as a means of veld reclamation in South Africa. South Afr. J. Bot. 69, 92-98. doi: 10.1016/S0254-6299(15)30363-X

Holechek, J. L., Gomes, H., Molinar, F., Galt, D., and Valdez, R. (2000). Short-term grazing: the facts in 1999. Rangelands 22, 18-22. doi: 10.2458/azu_rangelands_v22i1_holechek

Howard, A. (1940). An Agricultural Testament. New York, NY: Oxford University Press.

Howard, A. (1947). The Soil and Health. Lexington: University of Kentucky.

Howell, J. (2008). For the Love of Land: Global Case Studies of Grazing in Nature's Image. North Charleston, SC: BookSurge.

Ikerd, J. E. (2008). Crisis and Opportunity. Lincoln: University of Nebraska Press.

Imhoff, D. (Ed). (2010). The CAFO Reader: The Tragedy of Industrial Animal Factories. Berkeley, CA: University of California Press.

IPCC (2014). Climate Change 2014: Synthesis Report. Contribution of Working Groups I, II and III to the Fifth Assessment Report of the Intergovernmental Panel on Climate Change. Geneva: IPCC. 151.

IPCC (2018). Global Warming of $1.5^{\circ}$ C. An IPCC Special Report on the Impacts of Global Warming of $1.5^{\circ} \mathrm{C}$ Above Pre-Industrial Levels and Related Global Greenhouse Gas Emission Pathways, in the Context of Strengthening the Global Response to the Threat of Climate Change, Sustainable Development, and Efforts to Eradicate Poverty. Geneva: World Meteorological Organization, 32.

IPCC (2019). Climate Change and Land: An IPCC Special Report on Climate Change, Desertification, Land Degradation, Sustainable Land Management, Food Security, and Greenhouse Gas Fluxes in Terrestrial Ecosystems. Geneva.

Jackson, W. (2002). Natural systems agriculture: a truly radical alternative. Agric. Ecosyst. Environ. 88, 111-117. doi: 10.1016/S0167-8809(01) 00247-X

Janis, C. (2010). “An evolutionary history of browsing and grazing ungulates," in The Ecology of Browsing and Grazing, eds. I. J Gordon and H. H. T. Prins (Berlin: Springer), 21-45. doi: 10.1007/978-3-540-72422-3_2

Kelly, V. R., Lovett, G. M., Weathers, K. C., and Likens, G. E. (2005). Trends in atmospheric ammonium concentrations in relation to atmospheric sulfate and ammonia. Environ. Poll. 135, 363-369. doi: 10.1016/j.envpol.2004.11.009

Kleppel, G. (2014). The Emergent Agriculture. Gabriola Island, BC: New Society Publishers.

Kleppel, G. S. (2019). Microbial community structure in pasture and hayfield soils of the Helderberg region of New York State: a comparison of management strategies. Agroecol. Sustain. Food Syst. 43, 1031-1053. doi: 10.1080/21683565.2019.1591564

Kleppel, G. S., Girard, C., LaBarge, E., and Caggiano, S. (2011). Invasive plant control by livestock: from targeted eradication to ecosystem restoration. Ecol. Restor. 29, 209-211. doi: 10.3368/er.29.3.209

Lal, R. (2001). Soil degradation by erosion. Land Degrad. Dev. 12, 519-539. doi: $10.1002 / \mathrm{ddr} .472$

Lal, R. (2004). Carbon emission from farm operations. Environ. Int. 30, 981-990. doi: 10.1016/j.envint.2004.03.005

Lal, R. (2015). Sequestering carbon and increasing productivity by conservation agriculture. J. Soil Water Conserv. 70, 55A-62A. doi: 10.2489/jswc.70.3.55A

Lal, R. (2019). Conceptual basis of managing soil carbon: inspired by nature and driven by science. J. Soil Water Conserv. 74, 29A-34A. doi: 10.2489 /jswc.74.2.29A

Lal, R. (2020). Integrating animal husbandry with crops and trees. Front. Sustain. Food Syst. 4:113. doi: 10.3389/fsufs.2020.00113

Larson, W. E., Pierce, F. J., and Dowdy, R. H. (1983). The threat of soil erosion to long-term crop production. Science 219, 458-465. doi: $10.1126 /$ science. 219.4584 .458

Laycock, W. A., and Conrad, P. W. (1967). Effect of grazing on soil compaction as measured by bulk density on a high elevation cattle range. J. Range Manag. 20, 136-141. doi: $10.2307 / 3895792$ 
Liu, H., Li, J., Li, X., Zheng, Y., Feng, S., and Jiang, G. (2015). Mitigating greenhouse gas emissions through replacement of chemical fertilizer with organic manure in a temperate farmland. Sci. Bull. 60, 598-606. doi: 10.1007/s11434-014-0 679-6

Liu, J., Feng, C., Wang, D., Wang, L., Wilsey, B. J., and Zhong, Z. (2015). Impacts of grazing by different large herbivores in grassland depend on plant species diversity. J. Appl. Ecol. 52, 1053-1106. doi: 10.1111/1365-2664.12456

Lupo, C. D., Clay, D. E., Benning, J. L., and Stone, J. J. (2013). Life-cycle assessment of the beef cattle production system for the northern great plains, USA. J. Environ. Qual. 42, 1386-1394. doi: 10.2134/jeq2013.03.0101

Marion, B., Bonis, A., and Boulillé, J.-B. (2010). How much does grazing-induced heterogeneity impact plant diversity in wet grasslands? Ecoscience 17, 229-239. doi: 10.2980/17-3-3315

Massy, C. (2018). Call of the Reed Warbler. White River Junction, VT: Chelsea Green.

McCollum, F. T., Gillen, R. T., Karges, B. R., and Hodges, M. E. (1999). Stocker cattle response to grazing management in tallgrass prairie. J. Range Manag. 52, 120-126. doi: 10.2307/4003504

McNaughton, S. J. (1984). Grazing lawns: animals in herds, plant form, and coevolution. Am. Nat. 124, 863-886. doi: 10.1086/284321

McNaughton, S. J. (1985). Ecology of a grazing ecosystem: the serengeti. Ecol. Monographs 55, 259-294. doi: 10.2307/1942578

McNaughton, S. J. (1986). Grazing lawns: on domesticated and wild grazers. Am. Nat. 128, 937-939. doi: 10.1086/284615

McNaughton, S. J. (1990). Mineral nutrition and seasonal movements of African migratory ungulates. Nature 345, 613-615. doi: 10.1038/345613a0

Merrill, E. H., Stanton, N. L., and Hak, J. C. (1994). Responses of bluebunch wheatgrass, idaho fescue, and nematodes to ungulate grazing in yellowstone national park. Oikos 69, 231-240. doi: 10.2307/3546143

Meuret, M., and Provenza, F. (2014). The Art and Science of Shepherding. Greeley, CO: Acres, USA.

Milchunas, D. G., and Lauenroth, W. K. (1993). Quantitative effects of grazing on vegetation and soils over a global range of environments. Ecol. Monographs 63, 327-366. doi: 10.2307/2937150

Milchunas, D. G., Sala, O. E., and Lauenroth, W. K. (1988). A generalized model of the effects of grazing by large herbivores on grassland community. Am. Natural. 132, 87-106. doi: 10.1086/284839

Misselbrook, T. (2015). Ammonia and greenhouse gas emissions - Who emits more? Presented at Sustainable Food Trust Meeting (Rathansted). Available online at: https://www.slideshare.net/Sustainablefoodtrust/tom-misselbrook (accessed July 2, 2020)

Mligo, C. (2015). The impact of livestock grazing on soil characteristics in Mount Kilimanjaro, Tanzania. J. Geosci. Environ. Protect. 3, 24-37. doi: $10.4236 /$ gep.2015.39004

Montgomery, D. R. (2017). Growing a Revolution. New York, NY: W.W. Norton.

Nader, G., Tate, K. W., Atwill, R., and Bushnell, J. (1998). Water quality effect of rangeland beef cattle excrement. Rangelands 20, 19-25.

NAS (2015). "Global considerations for animal agriculture research," in Critical Role of Animal Science Research in Food Security and Sustainability, ed National Academy of Sciences (Washington, DC: National Academies Press), 215-309.

Oates, L. G., Undersander, D. J., Gratton, C., Bell, M. M., and Jackson, R. D. (2018). Management-intensive rotational grazing enhances forage production and quality of subhumid cool-season pastures. Crop Sci. 51, 892-901. doi: $10.2135 /$ cropsci2010.04.0216

Oksanen, L., Fretwell, S. D., Arruda, J., and Niemela, P. (1981). Exploitation ecosystems in gradients of primary productivity. Am. Nat. 118, 240-261. doi: $10.1086 / 283817$

Olivier, J. G. J., and Peters, J. A. H. W. (2018). Trends in Global $\mathrm{CO}_{2}$ and Total Greenhouse Gas Emissions. Publication Number 3125. The Hague: PBL Netherlands Environmental Assessment Agency.

Owen-Smith, N., Fryxell, J. M., and Merrill, E. H. (2010). Foraging theory upscaled: behavioral ecology of herbivore movement. Philos. Trans. Roy. Soc. B 365, 2267-2278. doi: 10.1098/rstb.2010.0095

Pain, B. F., Weerden, T. J., Chambers, B. J., Phillips, V. R., and Jarvis, S. C. (1998). A new inventory of ammonia emissions from UK agriculture. Atmosp. Environ. 32, 309-313. doi: 10.1016/S1352-2310(96)00352-4

Park, J.-Y., Ale, S., Teague, W. R., and Jeong, J. (2017). Evaluating the ranch and watershed scale impacts of using traditional and adaptive multi-paddock grazing on runoff, sediment and nutrient losses in North Texas, USA. Agric Ecosyst. Environ. 240, 32-44. doi: 10.1016/j.agee.2017.02.004

Parris, K. (2011). Impact of agriculture on water pollution in OECD Countries: recent trends and future prospects. Int. J. Water Res. Dev. 27, 33-52. doi: 10.1080/07900627.2010.531898

Patra, A. K., Abbadie, L., Clays-josserand,A., Degrange, V., Grayston, S. J., L'Oiseau, P., et al. (2005). Effects of grazing on microbial functional groups involved in soil N dynamics. Ecol. Monographs, 75 65-80. doi: 10.1890/0 3-0837

Pelletier, N., Pirog, R., and Rasmussen, R. (2010). Comparative life cycle environmental impacts of three beef production strategies in the upper midwestern united states. Agric. Syst. 103, 380-389. doi: 10.1016/j.agsy.2010.03.009

Pimentel, D. (1997). Soil erosion and agricultural productivity: the global population/food problem. GIAA 6, 197-204. doi: 10.14512/gaia.6.3.7

Pimentel, D. (2006). Soil erosion and agricultural productivity: the global population/food problem. Environ. Dev. Sustain. 8, 119-137. doi: 10.1007/s10668-005-1262-8

Pimentel, D., Allen, J., Beers, A., Guinand, L., Linder, R., McLaughlin, P., et al. (1987). World agriculture and soil erosion. BioScience 37, 277-283. doi: $10.2307 / 1310591$

Pimentel, D., and Burgess, M. (2013). Soil erosion threatens food production. Agriculture 3, 443-463. doi: 10.3390/agriculture3030443

Pimentel, D., Hepperly, P., Hanson, J., Douds, D., and Seidel, R. (2006). Environmental, energetic, and economic comparisons of organic and conventional farming systems. BioScience 55, 573-582. doi: 10.1641/0006-3568(2005)055[0573:EEAECO]2.0.CO;2

Pimentel, D., Stachow, U., Takacs, D. A., Brubaker, H. W., Dumas, A. R., Meaney, J. J., et al. (1992). Conserving biological diversity in agricultural/forestry systems. BioScience 42, 354-362. doi: 10.2307/1311782

Pollan, M. (2006). The Omnivore's Dilemma. New York, NY: Penguin Publishing.

Pollard, S. (1981). Peaceful Conquest: The Industrialization of Europe 1756-1970. New York, NY: Oxford University Press.

Revelle, R. (1976). The resources available for agriculture. Sci. Am. 235, 164-179. doi: 10.1038/scientificamerican0976-164

Rotz, C. A., Asem-Hiablie, S., Place, S., and Thoma, G. (2019). Environmental footprints of beef cattle production in the United States. Agric. Syst. 169, 1-13. doi: 10.1016/j.agsy.2018.11.005

Rotz, C. A., Corson, M. S., Chianese, D. S., Montes, F., Hafner, S. D., Bonifacio, H. F., et al. (2016). Integrated Farm System Model: USDA Agricultural Research Service, University Park, Pennsylvania. Available online at: https://www.ars. usda.gov/ARSUserFiles/80700500/Reference\%20Manual.pdf (accessed April 5 2018).

Rowntree, J. E., Ryals, R., DeLonge, M. S., Teague, W. R., Chiavegato, M. B., Byck, P., et al. (2019). Potential mitigation of midwest grass-finished beef production emissions with soil carbon sequestration in the United States of America. J. Food Agric. Soci. 4, 31-38.

Sacks, A. D., Teague, R., Provenza, F., Itzkan, S., and Laurie, J. (2014) "Restoring atmospheric carbon dioxide to pre-industrial levels: re-establishing the evolutionary grassland-grazer relationship," in Geotherapy, eds T. Goreau, R.W. Larson, J. Campe (Boca Raton, FL: CRC Press),155-194. doi: 10.1201/b13788-10

Salatin, J. (2019). Move 'em Every Day. Ridgeland: The Stockman - Grass Farmer.

Savory, A. (1978). "A holistic approach to ranch management using short duration grazing," in Proceedings of the 1st International Rangeland Congress, ed D. N. Hyder, ((Denver, CO: Society for Range Management), 555-557

Savory, A. (1983). The Savory grazing method or holistic resource management. Rangelands 5, 155-159.

Savory, A. (2013). How to Green the World's Deserts and Reverse Climate Change. Long Beach, CA: TEDxTalk. Available at: https:/www.bing.com/videos/ search?q=alan+savory+tedx+talkanddocid $=608046036138919958$ andmid $=$ A979A6423A680ED5400CA979A6423A680ED5400Candview= detailandFORM=VIRE (accessed July 8, 2020).

Savory, A., and Butterworth, J. (1999). Holistic Management, 2nd Edn. Washington, DC: Island Press.

Savory, A., and Butterworth, J. (2016). Holistic Management, 3rd Edn. Washington, DC: Island Press. 
Savory, A., and Parsons, S. (1980). The Savory grazing method. Rangelands 2:234-237.

Schlosser, C. A., Strzepek, K., Gao, X., Fant, C., Blanc, E., Paltsey, S., et al. (2014). The future of global water stress: an integrated assessment. Earth's Future 2, 341-361. doi: 10.1002/2014EF000238

Schlosser, E. (2001). Fast Food Nation. New York, NY: Houghton-Mifflin.

Sherren, K., and Kent, C. (2019). Who's afraid of Allan Savory? Scientometric polarization of Holistic Management as competing understandings. Renew. Agric. Food Syst. 34, 77-92. doi: 10.1017/S1742170517 000308

Shiva, V. (2016). The Violence of the Green Revolution. Lexington, KY: University of Kentucky Press.

Skarpe, C., and Hester, A. J. (2010). "Plant traits, browsing and grazing herbivores, and vegetation dynamics," in The Ecology of Browsing and Grazing, eds I. J. Gordon and H. H. T. Prins (Berlin: Springer), 217-261. doi: 10.1007/978-3-540-72422-3_9

Smith, F. A., Hammond, J. I., Balka, M. A., Elliott, S. M., Lyons, S. K., Pardia, M. I., et al. (2016). Exploring the influence of ancient and historic megaherbivore extirpations on the global methane budget. Proc. Natl. Acad. Sci. U.S.A. 113, 874-879. doi: 10.1073/pnas.1502547112

Sneath, R. W., Beline, F., Hilhorst, M. A., and Peu, P. (2006). Monitoring GHG from manure stores from organic and conventional dairy farms. Agric. Environ. Ecosyst. 112, 122-128. doi: 10.1016/j.agee.2005.08.020

Stanley, P. L., Rowntree, J. E., Beede, D. K., DeLonge, M. S., Hamm, M. W. et al. (2018). Impacts of soil carbon sequestration on life cycle greenhouse gas emissions in Midwestern USA beef finishing systems. Agric. Syst. 162, 249-258. doi: 10.1016/j.agsy.2018.02.003

Stuart-Hill, G. C., and Mentis, M. T. (1982). Coevolution of African grasses and large herbivores. Proc. Ann. Congr. Grassland Soc. South. Afr. 17, 122-128. doi: $10.1080 / 00725560.1982 .9648969$

Sutton, M. A., Dragosits, U., Tang, Y. S., and Fowler, D. (2000). Ammonia emissions from non-agricultural sources in the UK. Atmosp. Environ. 34, 855-869. doi: 10.1016/S1352-2310(99)00362-3

Teague, R. (2014). Deficiencies in the Briske et al. rebuttal of the Savory method. Rangelands 36, 37-38. doi: 10.2111/1551-501X-36.1.37

Teague, R., and Barnes, M. (2017). Grazing management that regenerates ecosystem function and grazingland livelihoods. Afr. J. Range Forage Sci. 34, 77-86. doi: 10.2989/10220119.2017.1334706

Teague, R., Provenza, F., Kreuter, U., Steffens, T., and Barnes, M. (2013). Multipaddock grazing on rangelands: why the perceptual dichotomy between research results and rancher experience? J. Environ. Manag. 128, 699-717. doi: 10.1016/j.jenvman.2013.05.064

Teague, W. R., Dowhower, S. L., Baker, S. A., Ansley, R. J., and Kreuter, U. P. (2020). Soil and herbaceous plant responses to patch burns under continuous and rotational grazing. Agric. Ecosyst. Environ. 137, 113-123. doi: $10.1016 /$ j.agee.2010.01.010

Teague, W. R., Dowhower, S. L., Baker, S. A., Haile, N., DeLaune, P. B., and Conover, D. M. (2011). Grazing management impacts on vegetation, soil biota, soil chemical, physical and hydrological properties in tall grass prairie. Agric. Ecosyst. Environ. 141, 310-322. doi: 10.1016/j.agee.2011.03.009

Teague, W. R., Provenza, F. D., Norton, B. E., Steffens, T., Barnes, M. K., Kothmann, M. M., and Roath, R. L. (2009). "Benefits of multi-paddock grazing on rangelands: Limitations of experimental grazing research and knowledge gaps," in Grasslands: Ecology, Management and Restoration, ed H. G. Schroder (New York, NY: Nova Science Publishers), 41-80.

Thurow, T. L., Blackburn, W. H., and Taylor, C. A. Jr. (1986). Hydrologic characteristics of vegetation types as affected by livestock grazing systems, edwards plateau, texas. J. Range Manage. 39, 505-509. doi: 10.2307/3898758

Tilman, D., Christian, B., Jason, H., and Befort, B. L. (2011). Global food demand and the sustainable intensification of agriculture. Proc. Natl. Acad. Sci. U.S.A. 108, 20260-20264. doi: 10.1073/pnas.1116437108

Toombs, T. P., and Roberts, M. G. (2009). Are natural resources conservation service range management investments working at cross-purposes with wildlife habitat goals on western United States Rangelands? Rangeland Ecol. Manag. 62, 351-355. doi: 10.2111/08-027.1

UMass (Sustainable UMass) (2020). Emissions. Amherst: University of Massachusetts. Available online at: https://www.umass.edu/sustainability/ climate-change-energy/emissions (accessed, June 29, 2020).
USDA/ERS (U.S. Department of Agriculture/ Economic Research Service) (2019a). Irrigation and Water Use. Available online at: file://C:/Users/gklep/Desktop/ Frontiers\%20Special\%20Issue/Kleppel\%20Frontiers\%20ms/References/USDA. \%202019.\%20Irrigation.pdf (accessed March 20, 2020).

USDA/ERS (U.S. Department of Agriculture/ Economic Research Service) (2019b). Irrigated Agriculture in the United States. Available online at: https:// www.ers.usda.gov/data-products/irrigated-agriculture-in-the-united-states/ (accessed March 20, 2020).

USEPA (U.S. Environmental Protection Agency) (2016). Toxicological Review of Ammonia Noncancer Inhalation. CASRN 7664-41-7, Washington, DC: US Environmental Protection Agency.

USEPA (U.S. Environmental Protection Agency) (2017). Polluted Runoff: Nonpoint Source Pollution, Nonpoint Source: Agriculture. Available online at: https:// 19january2017snapshot.epa.gov/nps/nonpoint-source-agriculture_.html (accessed March 20, 2020).

USEPA (U.S. Environmental Protection Agency) (2020). Draft Inventory of U.S. Greenhouse Gas Emissions and Sinks: 1990-2018. Available online at: https:// www.epa.gov/ghgemissions/draft-inventory-us- greenhouse-gas-emissionsand-sinks-1990-2018 (accessed March 20, 2020).

USGS (U.S. Geological Service) (2005). Estimated Use of Water in the United States: County-Level Data for 2005. (2005). Available online at: https://water.usgs.gov/ watuse/data/2005/ (accessed 1 September, 2020).

Vale, P., Gibbs, H., Vale, R., Christie, M., Florence, E., Munger, J., and Sabaini, E. (2019). The expansion of intensive beef farming to the Brazilian Amazon. Global Environ. Change 57:101922. doi: 10.1016/j.gloenvcha.2019.05.006

Venter, Z. S., Hawkins, H.-J., and Cramer, M. D. (2017). Implications of historical interactions between herbivoryand fire for rangeland management in African savannas. Ecosphere 8:e01946. doi: 10.1002/ecs2.1946

Verchot, L. V., Groffman, P. M., and Frank, D. A. (2002). Landscape versus ungulate control of gross mineralization and gross nitrification in semi-arid grasslands of Yellowstone National Park. Soil Biol. Biochem. 34, 1691-1699. doi: 10.1016/S0038-0717(02)00155-4

Villalba, J. J., and Provenza, F. D. (2009). Learning and dietary choice in herbivores. Rangeland Ecol. Manag. 62, 399-406. doi: 10.2111/08-076.1

Voisin, A. (1959). Grass Productivity. Washington, DC: Island Press.

Wang, T., Teague, W. R., and Park, S. C. (2016). Evaluation of continuous and multipaddock grazing on vegetation and livestock performance-a modeling approach. Rangeland Ecol. Manage. 69, 457-464. doi: 10.1016/j.rama.2016.07.003

Wang, T., Teague, W. R., Park, S. C., and Bevers, S. (2015). GHG mitigation potential of different grazing strategies in the United States Southern Great Plains. Sustainability 7, 13500-13521. doi: 10.3390/su71013500

Warren, S. D., Blackburn, W. H., and Taylor, C. A. Jr. (1986a). Soil hydrologic response to number of pastures and stocking density under intensive rotation grazing. J. Range Manag. 39, 500-504. doi: 10.2307/3898757

Warren, S. D., Thurow, T. L., Blackburn, W. H., and Garza, N. E. (1986b). The influence of livestock trampling under intensive rotation grazing on soil hydrologic characteristics. J. Range Manag. 39, 491-495. doi: 10.2307/3898755

Webb, J., Menzi, H., Pain, B. F., Misselbrook, T. H., Dämmgen, U., Hendricks, H., and Döhler, H. (2005). Managing ammonia emissions from livestock in Europe. Environ. Poll. 135, 399-406. doi: 10.1016/j.envpol.2004.11.013

Weiske, A.,Vabitsch, A., Olesen, J. E., Schelde, K., Michel, J., Friedrich, R., and Kaltschmitt, M. (2006). Mitigation of greenhouse gas emissions in European conventional and organic dairy farming. Agric. Ecosyst. Environ. 112, 221-232. doi: $10.1016 /$ j.agee.2005.08.023

White, R. R., and Hall, M. B. (2017). Nutritional and greenhouse gas impacts of removing animals from US agriculture. Proc. Natl. Acad. Sci. U.S.A. 114, E10301-E10308. doi/10.1073/pnas.1707322114 doi: 10.1073/pnas.170732 2114

Wiesner, M. E., Ruff, J. R., and Wheeler, W. B. (2015). Discovering the Western Past A Look at the Evidence. Clifton Park, NY: Cengage Learning.

Willett, W., Rockström, J., Loken, B., Springmann, M., Lang, T., Vermeulen, S., et al. (2019). Food in the anthropocene: the EAT-lancet commission on healthy diets from sustainable food systems. Lancet Commiss. 393, 447-492. doi: 10.1016/S0140-6736(18)31788-4

Wirsenius, S., Azar, C., and Berndes, G. (2010). How much land is needed for global food production under scenarios of dietary changes and livestock productivity increase in 2030. Agric. Syst. 103, 621-638. doi: 10.1016/j.agsy.2010.07.005 
Wynne, B. (1992). Uncertainty and environmental learning: Reconceiving science and policy in the preventive paradigm. Glob. Environ. Change 2, 111-127. doi: 10.1016/0959-3780(92)90017-2

Yamulki, S. (2006). Effect of straw addition on nitrous oxide and methane emissions from stored farmyard manures. Agric. Ecosyst. Environ. 112, 140-145. doi: 10.1016/j.agee.2005.08.013

Yoshitake, S., Soutome, H., and Koizumi, H. (2014). Deposition and decomposition of cattle dung and its impact on soil properties and plant growth in a cool-temperate pasture. Ecol. Res. 29, 673-684. doi: $10.1007 / \mathrm{s} 11284-014-1153-2$
Conflict of Interest: The author declares that the research was conducted in the absence of any commercial or financial relationships that could be construed as a potential conflict of interest.

Copyright (C) 2020 Kleppel. This is an open-access article distributed under the terms of the Creative Commons Attribution License (CC BY). The use, distribution or reproduction in other forums is permitted, provided the original author(s) and the copyright owner(s) are credited and that the original publication in this journal is cited, in accordance with accepted academic practice. No use, distribution or reproduction is permitted which does not comply with these terms. 